\title{
EFFECT OF PHYTASE SUPPLEMENTATION IN SOYBEAN MEAL BASED DIET ON NUTRIENT DIGESTIBILITY AND GROWTH PERFORMANCE OF GREEN CATFISH (Hemibagrus nemurus)
}

\author{
YULISMAN, DEDI JUSADI* and ING MOKOGINTA \\ Department of Aquaculture, Faculty of Fisheries and Marine Sciences, Bogor Agricultural University, \\ Kampus IPB Darmaga, Bogor, Indonesia
}

\begin{abstract}
This experiment was conducted to evaluate the effect of phytase supplemented to the diet on phosphorus (P) digestibility and growth performance of the green catfish Hemibagrus nemurus. Five kinds of experimental diets were used in this experiment, namely diets A, B, C, D and E. Diet A, as a control, was supplemented with inorganic $\mathrm{P}$, without phytase supplementation. Diet $\mathrm{B}, \mathrm{C}, \mathrm{D}$ and $\mathrm{E}$ were supplemented with $0,20,40$ and $60 \mathrm{mg}$ phytase $/ 100 \mathrm{~g}$ soybean meal (SBM), respectively, without inorganic P supplementation. Fifteen fish with initial body weight of $6.9 \pm 0.2$ $\mathrm{g}$ were stocked into each 60-1 aquarium. Fish were fed on the diets for 60 days. Results indicated that P digestibility increased from $64.5 \%$ to $87.0 \%$ as phytase supplement increased from $0 \mathrm{mg}$ in diet $\mathrm{B}$ to $60 \mathrm{mg}$ phytase/100 $\mathrm{g}$ SBM in diet $\mathrm{E}$. P digestibility in diet $\mathrm{E}$ was higher than that in diet A (77.6\%). The daily growth rate and feed conversion ratio followed similar trend. P, Ca and $\mathrm{Zn}$ concentration in the whole body and bone of fish fed diet $\mathrm{E}$ were higher than the fish fed diet $\mathrm{B}, \mathrm{C}$ and $\mathrm{D}$, but were insignificant compared to the fish fed diet A. Nitrogen $(\mathrm{N})$ and $\mathrm{P}$ loading by fish fed diet E were, respectively, $76 \%$ and $20 \%$ lower than those in fish fed the control diet. It is concluded that the inclusion of $60 \mathrm{mg}$ phytase/100 $\mathrm{g} \mathrm{SBM}$ in the diet of the green catfish could replace the utilization of inorganic $\mathrm{P}$ increase the digestibility of the diet thereby resulting in increased growth rate and reduced excretion of $\mathrm{P}$ and $\mathrm{N}$ into the waters.
\end{abstract}

Key words: Hemibagrus nemurus, phytase, soybean meal, phosphorus.

\section{INTRODUCTION}

The expansion of global aquaculture production increases the demand for aquaculture feeds. For carnivore species as green catfish Hemibagrus nemurus, protein can form up to $60 \%$ of the diet and fishmeal is the main source of dietary protein. Fishmeal is one of the most expensive and demanded ingredients and has become the main and most critical ingredient in aquafeed production. The increasing cost and demand of fishmeal has encouraged feed manufacturers to search for cheaper alternative protein source as plant protein.

Soybean meal (SBM) is a common plant protein source used as a substitute for

$\overline{\text { *Corresponding author: dedijusadi@yahoo.com }}$ 
fishmeal in the fish diet. It could replace $75 \%$ of fishmeal as a protein source in the diet of the green catfish (Pebriyadi 2004). A major obstacle in using SBM is their high phytic acid content. Phytic acid is a substance that contains unavailable phosphorus (P) to monogastric animals, including fish, because these animals lack phytase, which can hydrolyze phytic acid (Baruah et al. 2004). By using phytase supplement to the diet, the P digestibility can be improved. Li et al. (2004) reported that 250 units of phytase per $\mathrm{kg}$ diet could effectively replace di-calcium phosphate supplement in the diet of channel catfish without affecting growth, feed efficiency or bone phosphorus deposit. Masumoto et al. (2001) showed that $0.2 \mathrm{~g}$ of phytase supplement to the diet containing 67\% SBM increased the growth rate and feed efficiency of the Japanese flounder Paralicthys olivaceus. Therefore, using phytase supplement in the fish diet could increase the bioavailability of phosphorus of SBM. Hence, replacing the inorganic P of the diet, resulting in lower fecal P loss. This experiment was conducted to evaluate the effect of phytase supplement to the diet on P digestibility and growth performance of the green catfish Hemibagrus nemurus.

\section{MATERIALS AND METHODS}

\section{Experimental diets}

Five experimental diets were used in this experiment, namely diets A, B, C, D and E. Diet $A$, as a control, was supplemented with inorganic $\mathrm{P}\left(\mathrm{NaH}_{2} \mathrm{PO}_{4} \cdot \mathrm{H}_{2} \mathrm{O}, \mathrm{KH}_{2} \mathrm{PO}_{4}\right.$, $\left.\mathrm{Ca}_{2}\left(\mathrm{PO}_{4}\right)_{3}\right)$ only, without phytase supplement. Diet $\mathrm{B}, \mathrm{C}, \mathrm{D}$ and $\mathrm{E}$ were supplemented with 0, 20, 40 or $60 \mathrm{mg}$ phytase (Natuphos ${ }^{\circledR} 5000$ )/100 g SBM, respectively, without inorganic P supplement (Table 1). The proximate composition of experimental diets is shown in Table 2.

Table 1. Ingredients composition of experimental diet ( $\mathrm{g} / \mathrm{kg} \mathrm{diet})$

\begin{tabular}{|c|c|c|c|c|c|}
\hline \multirow{2}{*}{ Ingredients } & \multicolumn{5}{|c|}{ Treatments } \\
\hline & A & B & $\mathrm{C}$ & $\mathrm{D}$ & $E$ \\
\hline Fish meal ${ }^{1}$ & 130 & 130 & 130 & 130 & 130 \\
\hline Soybean meal ${ }^{1}$ & 640 & 640 & 640 & 640 & 640 \\
\hline Fish oil & 40 & 40 & 40 & 40 & 40 \\
\hline Soybean oil & 44 & 44 & 44 & 44 & 44 \\
\hline Tapioca $^{1}$ & 57 & 57 & 47,87 & 47,74 & 47,62 \\
\hline Vitamin mix & 15 & 15 & 15 & 15 & 15 \\
\hline Choline chloride & 5 & 5 & 5 & 5 & 5 \\
\hline L-Methionine & 5 & 5 & 5 & 5 & 5 \\
\hline Taurin & 6 & 6 & 6 & 6 & $\epsilon$ \\
\hline Mineral mix ${ }^{2}$ & 58 & 0 & 0 & 0 & 0 \\
\hline P-free mineral mix ${ }^{3}$ & 0 & 58 & 58 & 58 & 58 \\
\hline Phytase & 0 & 0 & 0.13 & 0.26 & 0.38 \\
\hline Citric acid & 0 & 0 & 9 & 9 & s \\
\hline \multicolumn{6}{|l|}{ P content (\%): } \\
\hline Total P & 1.46 & 0.55 & 0.55 & 0.56 & 0.58 \\
\hline Water-soluble P & 0.59 & 0.19 & 0.45 & 0.48 & 0.53 \\
\hline
\end{tabular}


Table 1. Continued

\begin{tabular}{cccccc}
\hline \multirow{2}{*}{ Ingredients } & \multicolumn{5}{c}{ Treatments } \\
\cline { 2 - 6 } & $\mathrm{A}$ & $\mathrm{B}$ & $\mathrm{C}$ & $\mathrm{D}$ & $\mathrm{E}$ \\
\hline Water-soluble P/total P ratio & 40.29 & 34.87 & 82.79 & 86.06 & 91.13 \\
\hline
\end{tabular}

1 Crude protein (dry weight) concentration of: fish meal 70.39\%, SBM 42.75\%, tapioca meal $0.91 \%$.

2 The mineral mix had the following composition ( $\mathrm{g} / \mathrm{kg}$ dry diet): $\mathrm{NaCl} 0.5 ; \mathrm{MgSO}_{4} .7 \mathrm{H}_{2} \mathrm{O} 7.5$; $\mathrm{NaH}_{2} \mathrm{PO}_{4} \mathrm{H}_{2} \mathrm{O}$ 12.5; $\mathrm{KH}_{2} \mathrm{PO}_{4} 16 ; \mathrm{Ca} 2\left(\mathrm{PO}_{4}\right)_{3}$ 14.49; Fe-citric 1.25; filler 3.60 and trace element $\operatorname{mix}(0.5 \mathrm{~g})$ had the following composition: $\mathrm{ZnSO}_{4} .7 \mathrm{H}_{2} \mathrm{O} 17.65 ; \mathrm{MnSO}_{4} 8.1 ; \mathrm{CuSO}_{4} .5 \mathrm{H}_{2} \mathrm{O} 1.55$; CoCl. $6 \mathrm{H}_{2} \mathrm{O} 0.05 ; \mathrm{KIO}_{3} 0.15$; and filler 30.5 (Takeuchi 1988).

3 P-free mineral mix had the following composition (g/kg dry diet): $\mathrm{NaCl} 0.5 ; \mathrm{MgSO}_{4} .7 \mathrm{H}_{2} \mathrm{O} 7.5 ; \mathrm{KCl}$ 17.53; Fe-citric 1.25; $\mathrm{CaCl}_{2} .2 \mathrm{H}_{2} \mathrm{O}$ 13.34; filler 30.5 and trace element mix $(0.5 \mathrm{~g})$ had the following composition: $\mathrm{ZnSO}_{4} .7 \mathrm{H}_{2} \mathrm{O} 17.365 ; \mathrm{MnSO}_{4} 8.1 ; \mathrm{CuSO}_{4} .5 \mathrm{H}_{2} \mathrm{O} 1.55 ; \mathrm{CoCl} .6 \mathrm{H}_{2} \mathrm{O} 0.05 ; \mathrm{KIO}_{3} 0.15$; and filler 30.5 .

Table 2. Proximate composition of experimental diets (\% wet weight)

\begin{tabular}{lrrrrr}
\hline \multirow{2}{*}{ Proximate Composition } & \multicolumn{5}{c}{ Treatments } \\
\cline { 2 - 6 } & \multicolumn{1}{c}{$\mathrm{A}$} & \multicolumn{1}{c}{$\mathrm{B}$} & \multicolumn{1}{c}{$\mathrm{C}$} & $\mathrm{D}$ & $\mathrm{E}$ \\
\hline Crude Protein & 31.19 & 29.49 & 29.30 & 30.11 & 29.19 \\
Crude Lipid & 10.58 & 10.62 & 10.18 & 10.30 & 9.92 \\
Ash & 11.09 & 8.74 & 8.92 & 9.12 & 8.79 \\
Water & 14.01 & 18.98 & 20.38 & 17.04 & 20.23 \\
Fiber & 4.20 & 3.21 & 2.62 & 2.92 & 2.24 \\
NFE $^{1}$ & 28.93 & 28.96 & 28.60 & 30.51 & 30.87 \\
Total Energy $^{2}(\mathrm{kcal} / 100 g)$ & 392.73 & 383.71 & 377.03 & 390.53 & 387.38 \\
Energy/Protein $\left(\mathrm{kcal} / \mathrm{g}\right.$ protein) $^{*}$ & 12.59 & 13.01 & 12.87 & 12.97 & 13.27 \\
\hline
\end{tabular}

${ }^{1}$ Nitrogen Free Extract.

${ }^{2}$ Total Energy (GE) was calculated based on equivalent values of: protein $5.6 \mathrm{Kcal} / \mathrm{g}$, lipid $9.4 \mathrm{Kcal} / \mathrm{g}$, and NFE 4.1 Kcal/g (Takeuchi, 1988).

For the pretreatment of SBM with phytase, $640 \mathrm{~g}$ of SBM was mixed with 2240 $\mathrm{ml}$ water, and then phytase was added to the SBM-water mixed at 20, 40, $60 \mathrm{mg} / 100 \mathrm{~g}$, respectively, in the diets $\mathrm{C}, \mathrm{D}$ and $\mathrm{E}$. The $\mathrm{pH}$ was adjusted to 5.5 with citric acid. The mixtures were incubated at $37^{\circ} \mathrm{C}$ for $2 \mathrm{~h}$ (Matsumoto et al. 2001). Then, the mixtures were mixed with other ingredients and formed into granules. The pellets were stored at $-20^{\circ} \mathrm{C}$ until use.

\section{Feeding trial}

Green catfish juveniles were obtained from the Main Center for Freshwater Aquaculture Development, Sukabumi, West Java, Indonesia. Upon arrival at the Laboratory of Fish Nutrition, of the Bogor Agricultural University, the fish were acclimated to experimental conditions for 10 days and fish readily adjusted to the experimental diets. Thereafter, fifteen juveniles with an initial body weight of $6.9 \pm 0.2 \mathrm{~g}$ were stocked into each 60-1 aquarium. Each aquarium was part of a closed recirculation system. During 
rearing period, each aquarium was supplied with continuous aeration and water was allowed to flow through at the rate of $200-300 \mathrm{ml} / \mathrm{min}$. Every day, impurities in the water of each aquarium were removed and $50 \%$ of the water was renewed to maintain water quality. From each aquarium, water was flown to the physical and biological filters, then in the conditioning tank. Thereafter, the water was drained back to each aquarium by using pump. Dissolved oxygen contents were 4.18-5.13 mg/l, water temperatures 28 to $30^{\circ} \mathrm{C}$, and $\mathrm{pH} 6.30$ to 6.35 . Each experimental diet was fed to the fish in three aquaria. The diets were randomly assigned to groups of fish in the aquarium. The fish were fed on the diets to satiation three times a day at $08.00,13.00$ and 18.00 hrs for 60 days.

At the end of the feeding trial, the fish of each aquarium were bulk weighed from each aquarium. Growth of the fish (as measured by the percentage of daily growth rate), feed conversion ratio (FCR), protein retention (PR) were calculated as described previously (Huisman 1976; Steffens 1989; Takeuchi 1988). After the final weighing, five fish were randomly sampled from each aquarium for body proximate and mineral compositions analysis, and three fish were randomly sampled from each aquarium for analyses of bone mineral (P, $\mathrm{Ca}$ and $\mathrm{Zn}$ ) composition. The proximate composition and mineral analyses were carried out according to the methods described by Takeuchi (1988).

\section{Digestibility trial}

The effect of phytase supplementation to the diet on the $\mathrm{P}$ digestibility was determined by the indirect method with $0.5 \%$ of chromic oxide $\left(\mathrm{Cr}_{2} \mathrm{O}_{3}\right)$ as an inert reference substance. The green catfish with the same size as that for the feeding trial were used in this digestibility trial. Twelve fish were stocked into each 60-1 aquarium. Triplicate groups of fish were fed on each experimental diet to satiation three times a day for 7 days prior to collection of feces. Feces were collected after $2 \mathrm{~h}$ of feeding by siphoning into a plastic sieve. After each collection, the samples from each aquarium were pooled, frozen at $-20{ }^{\circ} \mathrm{C}$ and stored for subsequent analyses. Feces collections were conducted for 21 days. Thereafter, the samples of feces were analyzed for chromium $(\mathrm{Cr}), \mathrm{P}$ and protein content according to the methods described by Takeuchi (1988). Apparent digestibility of total nutrient, protein, and $\mathrm{P}$ were calculated as follows:

$\%$ digestibility $=1-(\% \mathrm{Cr}$ in feed $/ \% \mathrm{Cr}$ in feces $) \times(\%$ ingredient in feces/ \% ingredient in feed) X 100

$\mathrm{P}$ and Nitrogen $(\mathrm{N})$ losses through feces were calculated as follows: $\mathrm{P}$ in feces $(\mathrm{g})=$ undigestible $\mathrm{P}(\%) \times \mathrm{P}$ consumption during culture period $\mathrm{N}$ in feces $(\mathrm{g})=$ (undigestible $\mathrm{N}(\%) \times \mathrm{N}$ consumption during culture period)/6.25

\section{Statistical methods}

The data were statistically analyzed for differences among the means by the oneway analysis of variance. The Duncan's test was used to compare treatment means using the statistical software SPSS 12 for windows. Differences were considered significant at $\mathrm{P}<0.05$. 


\section{RESULTS AND DISCUSSION}

Results indicated that $\mathrm{P}$ and protein digestibility increased from $64.5 \%$ to $87.0 \%$, and $87.1 \%$ to $90.5 \%$, respectively, as phytase supplement increased from $0 \mathrm{mg}$ in diet $\mathrm{B}$ to $60 \mathrm{mg}$ phytase/100 $\mathrm{g}$ SBM in diet E. P digestibility of diet $\mathrm{E}$ was higher than that of diet A (77.6\%) (Table 3). P digestibility was correlated with the water-soluble P. The water-soluble P content in control diet was $0.59 \%$. As the phytase supplement increased, water-soluble P increases from $0.19 \%$ in diet B to $0.53 \%$ in diet $\mathrm{E}$ (Table 1). It could be observed that the lowest $\mathrm{P}$ loss through feces was found for diet $\mathrm{E}$, and the lowest nitrogen $(\mathrm{N})$ loss through feces for diet $\mathrm{D}$. Diet $\mathrm{E}$ gave the second lowest $\mathrm{N}$ loss through feces. Level of $\mathrm{N}$ and $\mathrm{P}$ loading by fish fed diet $\mathrm{E}$ were $76 \%$ and $20 \%$, respectively, lower than those in the fish fed control diet (A).

Table 3. Phosphorus (P) and protein digestibility of experimental diets

\begin{tabular}{lccccc}
\hline \multirow{2}{*}{ Parameters } & \multicolumn{5}{c}{ Experiment } \\
\cline { 2 - 5 } & $\mathrm{A}$ & $\mathrm{B}$ & $\mathrm{C}$ & $\mathrm{D}$ & $\mathrm{E}$ \\
\hline P digestibility (\%) & 77.6 & 64.5 & 70.4 & 73.3 & 87.0 \\
P consumption (g) & $10.4 \pm 0.1^{\mathrm{d}}$ & $3.2 \pm 0.1^{\mathrm{a}}$ & $3.2 \pm 0.1^{\mathrm{a}}$ & $3 . .4 \pm 0.1^{\mathrm{b}}$ & $4.0 \pm 0.0^{\mathrm{c}}$ \\
P digested (g) & $8.1 \pm 0.1^{\mathrm{e}}$ & $2.0 \pm 0.0^{\mathrm{a}}$ & $2.3 \pm 0.0^{\mathrm{b}}$ & $2.5 \pm 0.1^{\mathrm{c}}$ & $3.5 \pm 0.1^{\mathrm{d}}$ \\
P output via feces (g) & $2.3 \pm 0.0^{\mathrm{e}}$ & $1.1 \pm 0.0^{\mathrm{d}}$ & $1.0 \pm 0.0^{\mathrm{c}}$ & $0.9 \pm 0.0^{\mathrm{b}}$ & $0.5 \pm 0.0^{\mathrm{a}}$ \\
Protein digestibilty (\%) & 89.1 & 87.1 & 85.1 & 89.7 & 90.5 \\
Protein consumption (g) & $257.4 \pm 2.8^{\mathrm{d}}$ & $207.6 \pm 3.5^{\mathrm{a}}$ & $215.6 \pm 3.5^{\mathrm{b}}$ & $218.2 \pm 4.1^{\mathrm{b}}$ & $251.8 \pm 1.0^{\mathrm{c}}$ \\
Nitrogen (N) digested (g) & $36.7 \pm 0.4^{\mathrm{c}}$ & $28.9 \pm 0.5^{\mathrm{a}}$ & $29.4 \pm 0.5^{\mathrm{a}}$ & $31.3 \pm 0.6^{\mathrm{b}}$ & $36.5 \pm 0.2^{\mathrm{c}}$ \\
N output via feces (g) & $4.5 \pm 0.1^{\mathrm{d}}$ & $4.3 \pm 0.1^{\mathrm{c}}$ & $5.1 \pm 0.1^{\mathrm{e}}$ & $3.6 \pm 0.1^{\mathrm{a}}$ & $3.8 \pm 0.0^{\mathrm{b}}$ \\
\hline
\end{tabular}

*) Values within the same row with different superscript letters are significantly different, $P<0.05$.

Concentrations of $\mathrm{P}, \mathrm{Ca}$ and $\mathrm{Zn}$ in the whole body and bone of the fish fed diet $\mathrm{E}$ were higher than those for the groups of fish fed on the diets supplemented with 0-40 mg phytase/100 g SBM, but were not significantly different from those of the fish fed diet A (Table 4).

Table 4. $\quad \mathrm{P}, \mathrm{Ca}$ and $\mathrm{Zn}$ content in green catfish (\% dry weight) fed experimental diets

\begin{tabular}{lrrrrr}
\hline \multirow{2}{*}{ Parameters } & \multicolumn{5}{c}{ Experiment } \\
\cline { 2 - 6 } & \multicolumn{1}{c}{$\mathrm{A}$} & $\mathrm{B}$ & $\mathrm{C}$ & $\mathrm{D}$ & \multicolumn{1}{c}{$\mathrm{E}$} \\
\hline Whole body & & & & \\
$\mathrm{P}$ & $3.18 \pm 0.28^{\mathrm{b}}$ & $2.08 \pm 0.27^{\mathrm{a}}$ & $2.34 \pm 0.39^{\mathrm{a}}$ & $2.97 \pm 0.19^{\mathrm{b}}$ & $3.20 \pm 0.12^{\mathrm{b}}$ \\
Ca & $3.26 \pm 0.06^{\mathrm{c}}$ & $1.92 \pm 0.30^{\mathrm{a}}$ & $2.12 \pm 0.07^{\mathrm{a}}$ & $2.90 \pm 0.20^{\mathrm{b}}$ & $3.30 \pm 0.09^{\mathrm{c}}$ \\
Zn & $0.012 \pm 0.001^{\mathrm{b}}$ & $0.009 \pm 0.001^{\mathrm{a}}$ & $0.012 \pm 0.000^{\mathrm{b}}$ & $0.012 \pm 0.001^{\mathrm{b}}$ & $0.013 \pm 0.002^{\mathrm{b}}$ \\
\hline
\end{tabular}


Table 4. Continued

\begin{tabular}{crrrrr}
\hline \multirow{2}{*}{ Parameters } & \multicolumn{5}{c}{ Experiment } \\
\cline { 2 - 6 } & \multicolumn{1}{c}{$\mathrm{A}$} & $\mathrm{B}$ & $\mathrm{C}$ & $\mathrm{D}$ & \multicolumn{1}{c}{$\mathrm{E}$} \\
\hline Bone & & & & \\
$\mathrm{P}$ & $21.41 \pm 1.12^{\mathrm{c}}$ & $13.44 \pm 0.26^{\mathrm{a}}$ & $16.65 \pm 0.77^{\mathrm{b}}$ & $16.99 \pm 1.24^{\mathrm{b}}$ & $21.46 \pm 0.43^{\mathrm{c}}$ \\
$\mathrm{Ca}$ & $33.33 \pm 0.11^{\mathrm{d}}$ & $21.44 \pm 1.15^{\mathrm{a}}$ & $24.42 \pm 0.76^{\mathrm{b}}$ & $26.04 \pm 1.15^{\mathrm{c}}$ & $33.60 \pm 1.66^{\mathrm{d}}$ \\
Zn & $0.032 \pm 0.002^{\mathrm{b}}$ & $0.021 \pm 0.002^{\mathrm{a}}$ & $0.023 \pm 0.002^{\mathrm{a}}$ & $0.024 \pm 0.003^{\mathrm{a}}$ & $0.032 \pm 0.001^{\mathrm{b}}$ \\
\hline
\end{tabular}

*) Values within the same row with different superscript letters are significantly different, $P<0.05$.

The mean body weight gain of the fish fed diet $\mathrm{E}$ was higher than that of the fish fed with the other diets. The daily growth rate and feed conversion ration (FCR) followed similar trend, while the fish fed diet B had the lowest daily growth rate and FCR (Table 5). The protein retention had the similar trend with the protein digestibility, which increased from $36.8 \%$ from $0 \mathrm{mg}$ phytase $/ 100 \mathrm{~g}$ SBM in the diet B to $44.4 \%$ from $60 \mathrm{mg}$ phytase/100 g SBM in the diet E.

Table 5. Initial body weight (Wo), final body weight (Wt), protein retention (PR), daily growth rate (DGR), feed consumption (FC), feed conversion ratio (FCR) and survival rate (SR) of green catfish

\begin{tabular}{lrrrrr}
\hline \multirow{2}{*}{ Parameters } & \multicolumn{5}{c}{ Treatments } \\
\cline { 2 - 6 } & \multicolumn{1}{c}{$\mathrm{A}$} & \multicolumn{1}{c}{$\mathrm{B}$} & \multicolumn{1}{c}{$\mathrm{C}$} & \multicolumn{1}{c}{$\mathrm{D}$} & $\mathrm{E}$ \\
\hline Wo (g) & $7.0 \pm 0.01$ & $7.0 \pm 0.02$ & $6.9 \pm 0.12$ & $6.8 \pm 0.09$ & $6.8 \pm 0.05$ \\
Wt (g) & $43.8 \pm 0.8$ & $31.9 \pm 1.1$ & $35.2 \pm 0.9$ & $40.2 \pm 0.4$ & $47.7 \pm 0.4$ \\
DGR (\%) & $3.1 \pm 0.0^{\mathrm{d}}$ & $2.6 \pm 0.1^{\mathrm{a}}$ & $2.8 \pm 0.1^{\mathrm{b}}$ & $3.0 \pm 0.0^{\mathrm{c}}$ & $3.3 \pm 0.0^{\mathrm{e}}$ \\
PR (\%) & $39.5 \pm 0.2^{\mathrm{b}}$ & $36.8 \pm 0.4^{\mathrm{a}}$ & $40.1 \pm 1.4^{\mathrm{b}}$ & $41.6 \pm 1.4^{\mathrm{b}}$ & $44.4 \pm 1.9^{\mathrm{c}}$ \\
FC (g) & $709.7 \pm 7.6^{\mathrm{e}}$ & $570.4 \pm 9.7^{\mathrm{a}}$ & $585.9 \pm 9.5^{\mathrm{b}}$ & $601.1 \pm 11.2^{\mathrm{c}}$ & $688.1 \pm 2.7^{\mathrm{d}}$ \\
FCR & $1.3 \pm 0.0^{\mathrm{c}}$ & $1.5 \pm 0.1^{\mathrm{e}}$ & $1.4 \pm 0.0^{\mathrm{d}}$ & $1,2 \pm 0.0^{\mathrm{b}}$ & $1.1 \pm 0.0^{\mathrm{a}}$ \\
SR (\%) & $100 \pm 0.0$ & $100 \pm 0.0$ & $100 \pm 0.0$ & $100 \pm 0.0$ & $100 \pm 0.0$ \\
\hline
\end{tabular}

*) Values within a row with different superscript letters are significantly different, $P<0.05$.

Increasing levels of phytase level from $0 \mathrm{mg}$ to $60 \mathrm{mg} / 100 \mathrm{~g}$ of SBM resulted in increasing levels of water-soluble $\mathrm{P}$, thereby increasing water-soluble $\mathrm{P} /$ total $\mathrm{P}$ ratios in the diets from $34.87 \%$ to $91.13 \%$. Diet $\mathrm{E}$ produced the highest $\mathrm{P}$ and protein digestibility, followed by diet A (control diet) (Table 3). It means that phytase released P from the insositol ring of phytate to be water-soluble P (Baruah et al. 2004). The water-soluble $\mathrm{P}$ was digested in the intestine of fish, and improved the absorption and utilization of P. Phytase also released some protein and amino acids from the phytic acid, hence the absorption and utilization of protein also increased. The same results were found for other fish species, such as the Atlantic salmon Salmo salar (Sajjadi and Carter 2004), striped bass Morone saxatilis (Papatryphon and Shoares 2001), rainbow trout Onchorhynchus mykiss (Cheng and Hardy 2004), Korean rockfish Sebastes schlegeli (Yoo et al. 2005), and tilapia Oreochromis niloticus (Liebert and Portz 2005). On the other hand, the fish fed on the diet $\mathrm{B}$ had the lowest $\mathrm{P}$ digestibility. It appears that the concentration of phytase in diet B could not enough release all P from phytic acid in the SBM. 
Table 4 shows that not only P availability in the diet could be improved by phytase supplementation, but also the other minerals as $\mathrm{Ca}$ and $\mathrm{Zn}$ which could be available to the fish. Accumulation of $\mathrm{Ca}, \mathrm{P}$ and $\mathrm{Zn}$ in the body and bone of fish also increased as the phytase levels of the diets increased from 0 to $60 \mathrm{mg} / 100 \mathrm{~g}$ SBM. Other experiments also showed that phytase supplemented diet increased $\mathrm{Ca}, \mathrm{P}$ and $\mathrm{Mn}$ contents of the African catfish Clarias gariepinus (Nwanna et al. 2005), striped bass Morone saxatilis (Hughes and Soares 1998), and Atlantic salmon Salmo salar (Sajjadi and Carter 2004).

It is known that phytic acid is the major P storage compound in plant seeds, including SBM. Phytic acid is also a strong chelator of important minerals such as Ca, $\mathrm{Mg}, \mathrm{K}, \mathrm{Fe}, \mathrm{Cu}, \mathrm{Zn}$ and forms poorly soluble complexes. Apart from minerals, phytic acid also forms complexes with protein and amino acids. The digestibility of these complexes by fish are very limited due to the lack of intestinal phytase (Pointillart et al.1987). The supplementation of phytase in this experiment could release those minerals and protein from phytic acid, resulted in increasing their (minerals and protein) digestibility for fish (Table $1 \& 3$ ), hence the absorption and utilization of minerals and protein also increased (Table $4 \& 5$ ). On the other hand, minerals also play a role in many processes of protein, lipid and carbohydrate metabolisms. Increasing the availability of some minerals in the diet by phytase supplementation also appears to improve the protein synthesis, which can be seen from the protein retention data (Table5). The highest protein retention was found in the groups of fish fed on diet E, while the fish fed on diet B had the lowest protein retention. The increased protein retention also improved the protein deposit in the body, hence increasing the daily growth rate (Table 5). In this experiment, the fish fed on diet $\mathrm{E}$ had the highest protein retention and daily growth rate. This indicates that phytase could increase the nutrient (protein) digestibility leading to higher protein retention, resulting in the increase of the growth rate and reduce feed conversion ratio. The same conclusions were also indicated by other authors that the phytase supplementation to SBM improved the weight and growth rate of juvenile Korean rockfish Sebates schlegeli (Yoo et al. 2005), tilapia Oreochromis niloticus (Liebert and Ports 2005; Furuya et al. 2001), rainbow trout Oncorhynchus mykiss (Vandenberg et al. 2003), and Pangasius pangasius (Debnath et al. 2005). Nwanna et al. (2005) also found that supplementation of phytase to a diet containing SBM gave better feed conversion than that for diet without phytase supplementation for the African catfish Clarias gariepinus, and the striped bass Morone saxatilis (Hughes and Soares 1998).

As earlier explained some of the diet consumed by fish was undigested, and will be excreted through feces. Increasing phytase concentration in the diet from $0 \mathrm{mg}$ to 60 $\mathrm{mg} / 100 \mathrm{~g}$ SBM reduced the levels of P and $\mathrm{N}$ excretion through feces. This indicated that phytase was able to release nutrient (protein) and minerals of phytate, resulting in the improvement of fish growth and also reduced $\mathrm{P}$ and $\mathrm{N}$ excretion through feces. Hughes and Soares (1998) concluded that phytase in a diet containing high level of plant protein could reduce the P excretion of striped bass Morone saxatilis, seabass Dicentrarchus labrax (Teles et al. 1998), Japanese flounder Paralichthys olivaceus (Masumoto et al. 2001), rainbow trout Oncorhynchus mykiss (Vielma et al. 2002), Atlantic salmon Salmo salar (Sajjadi and Carter 2004), tilapia Oreochromis niloticus (Furuya et al. 2001; Liebert and Portz 2005), and the African catfish Clarias gariepinus (Van Weerd et al. 1999; Nwanna et al. 2005), thereby reducing the loading of $P$ waste into the environment. 


\section{CONCLUSIONS}

The supplement of $60 \mathrm{mg}$ phytase/100 g SBM in the diet improved P digestibility and the growth of the green catfish Hemibagrus nemurus, hence reducing the loading of $\mathrm{P}$ and $\mathrm{N}$ waste to the environment.

\section{REFERENCES}

Baruah K., N.P. Sahu, A.K. Pal, and D. Debnath . 2004. Dietary phytase: an ideal approach for a cost effective and low-polluting aquafeed. NAGA, Worldfish Center Quarterly 27 (3) 3 \& 4 Jul-Dec 2004. p. 15-19.

Cheng ZJ, and R.W. Hardy . 2004. Effect of microbial phytase supplementation in corn distiller's dried grain with solubles on nutrient digestibility and growth performance of rainbow trout, Oncorhynchus mykiss. Journal of Applied Aquaculture. 15 (3/4): 83-100.

Debnath D., A.K. Pal, N.P. Sahu, K.K. Jain, S. Yengkokpam and S.C. Mukherjee. 2005. Effect of dietary microbial phytase supplementation on growth and nutrient digestibility of Pangasius pangasius fingerlings. Aquaculture Research (36) 2: 180 - 187.

Furuya W.M., G.S. Gonclaves, V.R.B. Furuya , C. and Hayashi. 2001. Phytase as feeding for Nile Tilapia (Oreochromis niloticus). Performance and digestibility. Rev. Bras. Zootec. 30: $924-929$.

Hughes K.P. and J.H. Soares Jr. 1998. Efficacy of phytase on phosphorus utilization in practical diets fed to striped bass Morone saxatilis. Aquaculture Nutrition, 4: 133 - 140.

Huisman E.A. 1976. Food conversion efficiencies at maintenance and production levels for carp (Cyprinus carpio Linn) and rainbow trout (Salmo gairdneri Ric.). Aquaculture, 9 (2): 259-273.

Liebert F. and L. Portz . 2005. Nutrient utilization of Nile tilapia (Oreochromis niloticus) fed plant based low phosphorus diets supplemented with graded levels of different sources of microbial phytase. Aquaculture, 248: $111-119$.

Li M.H., B.B. Manning and E.H. Robinson. 2004. Summary of phytase studies for channel catfish. Mississippi Agricultural and Forestry Experiment Station (23) 23 No. 13: 1-5.

Masumoto T., B. Tamura and S. Shimeno. 2001. Effects of phytase on bioavailabilty of phosphorus in soybean meal-based diets for japanese flounder (Paralichthys olivaceus). Fisheries Science, 67:1075-1080.

Nwanna L.C., O.A. Fagbenro and A.O. Adeyo. 2005. Effect of different treatments of dietary soybean meal and phytase on the growth and mineral deposition in African catfish Clarias gariepinus. Journal of Animal and Veterinary Advances. 4: $980-987$.

Papatryphon E., and J.H. Soares Jr. 2001. The effect of phytase on apparent digestibility of four practical plant feedstuffs fed to striped bass, Morone saxatilis. Journal Aquaculture Nutrition. 161-167.

Pebriyadi, B. 2004. Supplementation of methionine and tryptophan in the high soybean meal diets of juvenile green catfish (Mystus nemurus). Thesis (in Indonesian). Graduate School, Bogor Agricultural University. 53 p.

Pointillart A., A. Fourdin and N. Fontaine. 1987. Importance of cereal phytase activity for phytate phosphorus utilization by growing pigs fed diets containing triticale or corn. Journal of Nutrition 29: 907912 .

Sajjadi M. and C.G. Carter. 2004. Dietary phytase supplementation and the utilization of phosphorus by Atlantic salmon (Salmo salar L.) fed a canola-meal-based diet. Aquaculture 240: 417 - 431.

Takeuchi T. 1988. Laboratory work-chemical evaluation of dietary nutrients. p. 179-233, In Watanabe (Ed) Fish nutrition and mariculture. Kanagawa International Fisheries Training. Japan International Cooperation Agency (JICA), Japan. 
Teles A.O., J.P. Pereira, A. Gouveia and E. Gomes. 1998. Utilization of diets supplemented with microbial phytase by seabass (Dicentrarchus labrax) juvenils. Aquaculture Living Resources, 11 (4): 255259.

Vandenberg G.W., V. Dallaire, S.L. Scott and J. De la Noue . 2003. Encapsulation of microbial phytase : effects on phosphorus bioavailability in rainbow trout (Oncorhynchus mykiss). Aquaculture NutritionContributed papers. http://www.aquacultureassociation.ca/ac03/abstracts/nutrition.htm

Van Weerd J.H., K.H.A. Khalaf, F.J. Aartsen and P.A.T. Tjissen. 1999. Balance trials with African catfish Clarias gariepinus fed phytase-treated soybean meal based diets. Aquaculture Nutrition, 5:135142.

Vielma J., K. Ruohonen and M. Peisker . 2002. Dephytinization of two soy proteins increases phosphorus and protein utilization by rainbow trout, Oncorhynchus mykiss. Aquaculture. 204: 145-156.

Watanabe T. 1988. Fish nutrition and mariculture. JICA Textbook. The general aquaculture course. Department of Aquatic Biosciences. Tokyo University of Fisheries. 233 p.

Yoo G.Y., X. Wang, S. Choi , K. Han, J.C. Kang and S.C. Bai SC. 2005. Dietary microbial phytase increased the phosphorus digestibility in juvenile Korean rockfish Sebastes schlegeli fed diets containing soybean meal. Aquaculture 243. $315-322$. 